\title{
The Risk Factors of Type 2 Diabetic Patients Attending Rajshahi Diabetes Association, Rajshahi, Bangladesh and Its Primary Prevention
}

\author{
Rafiqul Islam*, Obaidur Rahman \\ Department of Population Science and Human Resource Development, Rajshahi University, Bangladesh
}

\begin{abstract}
Diabetes is a serious harmful disease. The purpose of this study is to find out the risk factors of Type 2 diabetic patients in Bangladesh. For this purpose, the data are collected from the diabetic patients of Rajshahi Diabetes Association, Bangladesh. To fulfill this objective, chi square test and logistic regression analysis have been used. It is found that diabetes affects more in the age 35 years and over which is $89.7 \%$ in which $68.3 \%$ have type 2 diabetes. Again, $79.3 \%$ of diabetic patients have type 2 diabetes in which females (43.7\%) are more affected than males (35.7\%). It has been found that age, controlling diabetic through exercise, controlling diabetic through taking medicine and living house of the respondents are significantly associated with the type 2 diabetes of diabetic patients. It is also identified from logistic model that respondent's age, occupation, controlling diabetic through dieting, controlling diabetic through exercise, controlling diabetic through taking medicine, time spending in walking, calorie intake according to diabetic food table and living house of the respondents have statistically significant effect on type 2 diabetes.
\end{abstract}

Keywords Type 2 Diabetes, Chi Square Test, Logistic Regression Analysis And Cross- Validity Prediction Power (CVPP)

\section{Introduction}

Diabetes is classed as a metabolism disorder. It is a group of diseases characterized by high levels of blood glucose resulting from defects in insulin production, insulin action and both, and is associated with serious complications and premature death. Also, diabetes mellitus is a major public health care problem with increasing incidence and long term complications. It is a leading cause of illness and death across the world which is associated with continuing damage, dysfunction and failure of various organs including lungs[1]. The most common form of diabetes is type 2 diabetes which occurs when the pancreas is usually producing enough insulin but for unknown reasons the body can't use the insulin effectively (this condition is called insulin resistance).

Diabetes is an emerging issue in developing as well as developed countries of the world. It was estimated that the number of people with diabetes globally would increase from current 171 million to 366 by 2030[2]. In developed countries like United States which is one of the most vulnerable places in terms of number of diabetic patients in which diabetes was the seventh leading cause of death listed

* Corresponding author:

rafique_pops@yahoo.com (Rafiqul Islam)

Published online at http://journal.sapub.org/fph

Copyright (C) 2012 Scientific \& Academic Publishing. All Rights Reserved on U.S. death certificates in 2006[3]. An estimated 23.6 million people in the United States have diabetes which is about $7.8 \%$ of the total population. Of those, 17.9 million have been diagnosed and 5.7 million have not yet been diagnosed. In 2007, about 1.6 million people of ages 20 and older were diagnosed with diabetes, 57 million people and 2 million adolescents have pre-diabetes. 186300 (actually $0.22 \%$ ) people under 20 years old have diabetes in which 1 in every 400 to 600 under 20 years old have type 1 diabetes. According to American Diabetes Association (2007), about $3 \%$ to $8 \%$ of pregnant women in the United States develop gestational diabetes, cases of diabetes doubled from 1990 to 2005 and by 2050, 48 million Americans will have type 2 diabetes[3].

An emerging epidemic of diabetes is affecting more people in low income than high income countries[2]. Diabetes poses a serious threat to developing countries like Bangladesh because the income of the most of the people in Bangladesh is very low. So Bangladesh is no longer in the safe area as far as the prevalence of this pandemic is concerned. Studies in various populations in Bangladesh have reported a prevalence of diabetes from $4 \%$ to $13 \%$ among adults with some variations by urban and rural settings[4-6]. BIRDEM (Bangladesh Institute of Research and Rehabilitation in Diabetes, Endocrine and Metabolic Disorders) is now providing diabetic care to almost 3.5 lacs patients from which about 3500 registered patients are taking health services 
from BIRDEM OPD every day[7]. In a small survey it is indicated that the prevalence of diabetes in Bangladesh in populations aged over 15 years is between $2 \%-5 \%$ [7]. It was estimated that about $90 \%-95 \%$ of all diabetes patients of Bangladesh belonged to type 2 diabetes[2]. They also mentioned that Bangladesh currently has over three million people with diabetes and this number will reach 11 million by the year 2030. If this situation continues, Bangladesh will face severe crisis. As a developing country, it does not have the resource to tackle this situation. So, it is important to identify the risk factors and to prevent this epidemic. It was seen that the related risk factors were older age, duration of diabetes, poor control of diabetes and hypertension[8]. Some studies reported that age, hypertension and body mass index (especially overweight and obesity) were significantly and independently associated with an increase in type 2 diabetes [9-12]. It was observed that sex and hypertension is as independent factors for the abnormalities in glucose tolerance [13]. Besides this, age, sex, higher income and waist to hip ratio appeared to be important risk factors for the occurrence of type 2 diabetes in Bangladeshi population[4,5,14]. Again, it was concluded that the risk factors for type 2 diabetes are likely to differ in different population[14].

Bangladesh is an agro-based South-Asian delta and predominantly rural with high density. The population of Bangladesh is increasing day by day. In this situation, it would be difficult to ensure basic needs including food, cloth, education, shelter, health and communication for a large number of populations within the limited geographic area. Besides this, the literacy rate is very low. The female literacy rate is $38.1 \%$ where as the male literacy rate is $55.61 \%[15]$. Not only the illiterate person but also most of the literate person are not conscious about their health. Because of poor economy they do not get proper health service. Most of them don't know about their diabetic situation. But undiagnosed pre-diabetes and diabetes is a major health problem[16]. Also, ICDDR,B (2009) found that diabetes and pre-diabetic conditions exist as a significant but hidden public health problem in Matlab and suggested that primary prevention may reduce the burden of diabetes in the community[17]. Studies in Finland, the United States, and China demonstrated that diabetes can be prevented in more than half of the individuals with pre-diabetic conditions through interventions to modify lifestyles[18-20]. Although the population with pre-diabetic conditions is always much larger than the diabetic population, it offers an opportunity for primary prevention. So, the objective of this study is to identify the risk factors of type 2 diabetes and recommend some appropriate policy for primary prevention of type 2 diabetes.

\section{Data and Methodology}

A total number of 300 diabetic patients (140 male and 160 female) were interviewed during 13 August 2009 to 29 October 2009 by some selected socio-economic, demographic, diabetic disease and health consciousness related question from Rajshahi Diabetes Association, Rajshahi, Bangladesh by purposive sampling technique. The bivariate and logistic regression analysis has been used for above objective. Bivariate analysis is used to test the association between the categorical variables by applying chi square test. But bivariate analysis does not allow for quantification or testing the strength of the risk factors of diabetic patients among selected variables. For that reason, logistic analysis is used to identify the significant variables and determinants of type 2 diabetes. Logistic regression analysis is very useful for identifying various risk factors in case of qualitative variables. 24 Cox developed linear logistic regression model [21]. Later, Lee also developed logistic regression model [22]. The logistic regression model can be not only to identify the risk factors but also to predict the probability of success. This model expresses a qualitative dependent variable as a function of several independent variables, both qualitative and quantitative[23]. In logistic analysis, type 2 diabetes is considered as dependent variable. Let, $\mathrm{Y}$ be type 2 diabetes that is a dichotomous dependent variable, which takes values 1 and 0 , that is, $\mathrm{Y}$ is classified in the following way:

$$
\mathrm{Y}=\left\{\begin{array}{l}
1, \text { if the respondents have type } 2 \text { diabetes } \\
0, \text { otherwise }
\end{array}\right.
$$

It is noted that the explanatory variables used in this model are mentioned in Table 2.

In this paper, to assess the accuracy and reliability of the model, the CVPP, $\rho_{\mathrm{cv}}^{2}$, is applied. The mathematical formula for CVPP is specified by

$$
\rho_{c v}^{2}=1-\frac{(n-1)(n-2)(n+1)}{n(n-k-1)(n-k-2)}\left(1-R^{2}\right) .
$$

In which, $\mathrm{n}$ is the number of cases, $\mathrm{k}$ is the number of regressors in the fitted model and the cross-validated $\mathrm{R}$ is the correlation between observed and predicted values of the predictand variable[24]. The shrinkage of the model is the positive value of $\left(\rho_{\mathrm{cv}}^{2}-R^{2}\right)$; where $\rho_{\mathrm{cv}}^{2}$ is CVPP $\& R^{2}$ is the coefficient of determination of the model. Moreover, 1 -shrinkage is the stability of $\mathrm{R}^{2}$ of the model. The estimated CVPP and shrinkage are presented at the bottom of Table 2.

\section{Results and Discussion}

The result of association between type 2 diabetes among some selected socio-economic, demographic, diabetic disease and health consciousness related characteristics of diabetic patients have been demonstrated in Table 1. Table 1 reveals that most of the diabetic patients are belonged in the middle and older age group. Diabetes affects more in the age 35 years and over which is $89.7 \%$ of which $68.3 \%$ of the total respondent have type 2 diabetes. In middle age group, $32.3 \%$ out of $40.7 \%$ and in older age group, $36 \%$ out of $49 \%$ diabetic patients have type 2 diabetes. It is similar to other studies. It was observed that prevalence of diabetes was associated with increasing age[25]. Also, it was showed a 
higher diabetes mellitus rate in older people[8]. Again, total $79.3 \%$ diabetic patients have type 2 diabetes in which $35.7 \%$ and $43.7 \%$ are male and female respectively. So it is clear that females are more affected by type 2 diabetes than males. It is observed that professional persons (23\%) are less affected by type 2 diabetes than non professional persons $(51 \%)$. Among the total no. of diabetic patients, type 2 diabetes affects more in literate persons $(42.3 \%)$ than illiterate persons $(31.7 \%)$. The majority no. of diabetes patients is suffering from diabetes less than one year which is $36.3 \%$ in which $26.7 \%$ patients have type 2 diabetes. Most of the diabetic patients (47.3\%) are sleeping more than normal ( $>6$ hours) where $35 \%$ have type 2 diabetes, $24.3 \%$ and $28.3 \%$ diabetic patients are sleeping normal (6 hours) and less than normal ( $<6$ hours) respectively in which $17.7 \%$ and $21.3 \%$ have type 2 diabetes respectively. There are $29.7 \%$ and $64.3 \%$ diabetic patients who have over weight and normal weight respectively where $23 \%$ over weighted and $47 \%$ normal weighted patients have type 2 diabetes. Among total respondents, $48.3 \%, 19.3 \%$ and $6.3 \%$ respondents who have normal, high and low blood pressure respectively has type 2 diabetes. Again, the majority no. of diabetic patients (63.3\%) has one or more diabetic patients in their family where $47 \%$ have type 2 diabetes and there are about half of the total respondents $(51 \%)$ whose diabetes is increasing because of food habit in which $37.3 \%$ have type 2 diabetes. There are $72.6 \%, 59.3 \%$ and $42.7 \%$ type 2 diabetic patients who are controlling their diabetes through dieting, exercise and medicine respectively. Again, $38.7 \%, 29.3 \%$ and $6 \%$ type 2 diabetic patients are spending their time in walking for $\leq 30$ minutes, 31-60 minutes and $>60$ minutes respectively. Again, 59.4\%, 11.4\% and 3\% respondents who has type 2 diabetes gets daily within the range of 1000-1500 calorie, 1600-1800 calorie and 1800+ calorie from foods according to diabetic food table (DFT) respectively. Most of the living house of the respondents is tin shed which is $44 \%$ of which $35.7 \%$ have type 2 diabetes, $33 \%$ respondents and $23 \%$ respondents have their living house as building and mud made respectively of which $21.7 \%$ and $16.7 \%$ have type 2 diabetes respectively.

From the Table 1, it is also found that age, controlling diabetic through exercise, controlling diabetic through taking medicine and living house of the respondents are significantly associated with the type 2 diabetes of diabetic patients. This result is also reflected in the study by[10]. It was identified that older age and poor control of diabetes are significantly associated with an increase in diabetes[8]. On the other hand, sex, education, occupation, duration of suffering from diabetic, duration of sleeping, overweight, normal weight, blood pressure, family history of diabetic patients, controlling diabetic through dieting, increasing diabetes because of food habit, time spending in walking and calorie intake according to DFT are insignificantly associated with the type 2 diabetes of diabetic patients.

The results of logistic regression model are shown in Table 2. According to the fitted model, there are eight variables out of seventeen variables appear as the approximately sig- nificant predictors of type 2 diabetes of the diabetic patients. In accordance with their importance, respondent's age, occupation, controlling diabetic through dieting, controlling diabetic through exercise, controlling diabetic through taking medicine, time spending in walking and living house of the respondents have statistically significant effect on type 2 diabetes and calorie intake according to diabetic food table have statistically approximately significant effect on type 2 diabetes. On the other hand, respondent's sex, education, duration of sleeping, duration of suffering from diabetic, increasing diabetes because of food habit, existence of any diabetic patients in the family, overweight, normal weight and blood pressure have no any statistically significant effect on type 2 diabetes. Moreover, from the Table 2 it appears that the fitted model is $40 \%$ cross- validated and the corresponding shrinkage coefficient is 0.076009 . This implies that the fitted model be stable more than $33 \%$. The stability for $\mathrm{R}^{2}$ of this model is more than $92 \%$.

The regression coefficients of the respondent's current age are being calculated. From this result, it is appeared that the respondent's current age is the most significant factor affecting the type 2 diabetes. It has also been found in bivariate analysis. The regression coefficient of middle age and older age are 1.266 and 0.636 respectively and the corresponding odds ratio is 3.545 and 1.890 respectively. It indicates that the middle aged and older aged diabetes patients are 3.545 times and 1.890 times more in risk to develop the type 2 diabetes than that of earlier aged diabetic patients respectively which is also similar to the study conducted by $[5,8,14$, 26]. It is clear that middle aged population have greater risk to develop type 2 diabetes than other aged population.

The logistic regression coefficient of professional respondents is 0.876 and the corresponding odds ratio is 2.400 which imply that the risk of type 2 diabetes for professional respondents is 2.400 times higher than that of non- professional respondents. Although professional respondents earn more than non-professionals, professional respondents have high risk to develop type 2 diabetes because they do not get enough time to exercise as well as physical movement. This result is supported by [5] because they identified that higher income was a significant risk factor of type 2 diabetes.

The regression coefficients of the respondents who are controlling their diabetes through dieting, exercise and taking medicine are $1.771,1.608$ and 2.517 respectively and their corresponding odds ratio are 5.876, 4.991 and 12.390 respectively. It indicates that the risk of the type 2 diabetes of the respondents who are controlling their diabetes through dieting are 5.876 times higher than that of respondents who are not controlling their diabetes through dieting, the risk of the type 2 diabetes of the respondents who are controlling their diabetes through exercise are 4.991 times higher than that of respondents who are not controlling their diabetes through exercise and the risk of the type 2 diabetes of the respondents who are controlling their diabetes through taking medicine are 12.390 times higher than that of respondents who are not controlling their diabetes through taking medicine. This result also clarify that poor control of diabetes is another risk factor of diabetes which is similar to another study done[10]. 
Table 1. Association between Type 2 Diabetes and Some Selected Socio-economic, Demographic, Diabetic Disease and Health Consciousness Related Variable of Diabetic Patients

\begin{tabular}{|c|c|c|c|c|c|}
\hline \multirow{2}{*}{ Variables } & \multicolumn{2}{|c|}{ Type 2 Diabetes } & \multirow[b]{2}{*}{ Total } & \multirow{2}{*}{$\chi_{c a l}^{2}, \chi_{\text {tab }}^{2}$ and $\rho$ Value } & \multirow{2}{*}{$\begin{array}{l}\text { Significance } \\
\text { Level of Asso- } \\
\text { ciation at } 10 \%\end{array}$} \\
\hline & No & Yes & & & \\
\hline $\begin{array}{c}\text { Age Group } \\
\text { Early Age }(<35 \text { years }) \\
\text { Middle Age }(35-50 \text { years }) \\
\text { Older Age }(>50 \text { years }) \\
\text { Total } \\
\end{array}$ & $\begin{array}{l}14(4.7 \%) \\
25(8.3 \%) \\
39(13.0 \%) \\
78(26.0 \%) \\
\end{array}$ & $\begin{array}{l}17(5.7 \%) \\
97(32.3 \%) \\
108(36.0 \%) \\
222(74.0 \%) \\
\end{array}$ & $\begin{array}{l}31(10.3 \%) \\
122(40.7 \%) \\
147(49.0 \%) \\
300(100 \%) \\
\end{array}$ & $\begin{array}{c}\chi_{\text {cal }}^{2}=7.861, \mathrm{df}=2 \\
\chi_{\text {tab }}^{2}=4.61 \\
\rho=0.020\end{array}$ & Significant \\
\hline $\begin{array}{c}\text { Sex } \\
\text { Male } \\
\text { Female } \\
\text { Total } \\
\end{array}$ & $\begin{array}{l}33(11.0 \%) \\
29(9.7 \%) \\
62(20.7 \%) \\
\end{array}$ & $\begin{array}{l}107(35.7 \%) \\
131(43.7 \%) \\
238(79.3 \%) \\
\end{array}$ & $\begin{array}{l}140(46.7 \%) \\
160(53.3 \%) \\
300(100 \%) \\
\end{array}$ & $\begin{array}{c}\chi_{c a l}^{2}=1.351, \mathrm{df}=1 \\
\chi_{\text {tab }}^{2}=2.71 \\
\rho=0.245\end{array}$ & Insignificant \\
\hline $\begin{array}{c}\text { Occupation } \\
\text { Non Professional } \\
\text { Professional } \\
\text { Total } \\
\end{array}$ & $\begin{array}{l}55(18.3 \%) \\
23(7.7 \%) \\
78(26.0 \%) \\
\end{array}$ & $\begin{array}{l}153(51.0 \%) \\
69(23.0 \%) \\
222(74.0 \%) \\
\end{array}$ & $\begin{array}{l}208(69.3 \%) \\
92(30.7 \%) \\
300(100 \%) \\
\end{array}$ & $\begin{array}{c}\chi_{\text {cal }}^{2}=0.069, \mathrm{df}=1 \\
\chi_{\text {tab }}^{2}=2.71 \\
\rho=0.793\end{array}$ & Insignificant \\
\hline $\begin{array}{c}\text { Education } \\
\text { Illiterate } \\
\text { Literate } \\
\text { Total } \\
\end{array}$ & $\begin{array}{l}27(9.0 \%) \\
51(17.0 \%) \\
78(26.0 \%) \\
\end{array}$ & $\begin{array}{l}95(31.7 \%) \\
127(42.3 \%) \\
222(74.0 \%) \\
\end{array}$ & $\begin{array}{l}122(40.7 \%) \\
178(59.3 \%) \\
300(100 \%) \\
\end{array}$ & $\begin{array}{c}\chi_{c a l}^{2}=1.600, \mathrm{df}=1 \\
\chi_{\text {tab }}^{2}=2.71 \\
\rho=0.206\end{array}$ & Insignificant \\
\hline $\begin{array}{c}\text { Duration of Suffering from Diabetic } \\
<1 \text { year } \\
1-5 \text { years } \\
6-10 \text { years } \\
>10 \text { years } \\
\text { Total }\end{array}$ & $\begin{array}{l}29(9.7 \%) \\
24(8.0 \%) \\
18(6.0 \%) \\
7(2.3 \%) \\
78(26.0 \%)\end{array}$ & $\begin{array}{c}80(26.7 \%) \\
77(25.7 \%) \\
39(13.0 \%) \\
26(8.7 \%) \\
222(74.0 \%) \\
\end{array}$ & $\begin{array}{l}109(36.3 \%) \\
101(33.7 \%) \\
57(19.0 \%) \\
33(11.0 \%) \\
300(100 \%)\end{array}$ & $\begin{array}{c}\chi_{c a l}^{2}=1.599, \mathrm{df}=3 \\
\chi_{\text {tab }}^{2}=6.25 \\
\rho=0.660\end{array}$ & Insignificant \\
\hline $\begin{array}{c}\text { Duration of Sleeping } \\
\text { Less than Normal }(<6 \text { hour }) \\
\text { Normal }(6 \text { hour }) \\
\text { More than Normal }(>6 \text { hour }) \\
\text { Total } \\
\end{array}$ & $\begin{array}{l}21(7.0 \%) \\
20(6.7 \%) \\
37(12.3 \%) \\
78(26.0 \%) \\
\end{array}$ & $\begin{array}{l}64(21.3 \%) \\
53(17.7 \%) \\
105(35.0 \%) \\
222(74.0 \%) \\
\end{array}$ & $\begin{array}{l}85(28.3 \%) \\
73(24.3 \%) \\
142(47.3 \%) \\
300(100 \%) \\
\end{array}$ & $\begin{array}{c}\chi_{\text {cal }}^{2}=0.148, \mathrm{df}=2 \\
\chi_{\text {tab }}^{2}=6.25 \\
\rho=0.929\end{array}$ & Insignificant \\
\hline $\begin{array}{l}\text { Over Weight } \\
\text { No } \\
\text { Yes } \\
\text { Total }\end{array}$ & $\begin{array}{l}58(19.3 \%) \\
20(6.7 \%) \\
78(26.0 \%)\end{array}$ & $\begin{array}{l}153(51.0 \%) \\
69(23.0 \%) \\
222(74.0 \%)\end{array}$ & $\begin{array}{l}211(70.3 \%) \\
89(29.7 \%) \\
300(100 \%)\end{array}$ & $\begin{array}{c}\chi_{\text {cal }}^{2}=0.819, \mathrm{df}=1 \\
\chi_{\text {tab }}^{2}=2.71 \\
\rho=0.366\end{array}$ & Insignificant \\
\hline $\begin{array}{c}\text { Normal Weight } \\
\text { No } \\
\text { Yes } \\
\text { Total }\end{array}$ & $\begin{array}{l}26(8.7 \%) \\
52(17.3 \%) \\
78(26.0 \%)\end{array}$ & $\begin{array}{l}81(27.0 \%) \\
141(47.0 \%) \\
222(74.0 \%)\end{array}$ & $\begin{array}{l}107(35.7 \%) \\
193(64.3 \%) \\
300(100 \%)\end{array}$ & $\begin{array}{c}\chi_{c a l}^{2}=0.250, \mathrm{df}=1 \\
\chi_{\text {tab }}^{2}=2.71 \\
\rho=0.617\end{array}$ & Insignificant \\
\hline $\begin{array}{l}\text { Blood Pressure } \\
\text { Normal } \\
\text { High } \\
\text { Low } \\
\text { Total } \\
\end{array}$ & $\begin{array}{l}44(14.7 \%) \\
25(8.3 \%) \\
9(3.0 \%) \\
78(26.0 \%) \\
\end{array}$ & $\begin{array}{c}145(48.3 \%) \\
58(19.3 \%) \\
19(6.3 \%) \\
222(74.0 \%) \\
\end{array}$ & $\begin{array}{c}189(63.0 \%) \\
83(27.7 \%) \\
28(9.3 \%) \\
300(100 \%) \\
\end{array}$ & $\begin{array}{c}\chi_{\text {cal }}^{2}=2.008, \mathrm{df}=2 \\
\chi_{\text {tab }}^{2}=4.61 \\
\rho=0.366\end{array}$ & Insignificant \\
\hline $\begin{array}{c}\text { Family History of Diabetic Patients } \\
\text { No } \\
\text { Yes } \\
\text { Total }\end{array}$ & $\begin{array}{l}29(9.7 \%) \\
49(16.3 \%) \\
78(26.0 \%)\end{array}$ & $\begin{array}{l}81(27.0 \%) \\
141(47.0 \%) \\
222(74.0 \%)\end{array}$ & $\begin{array}{l}110(36.7 \%) \\
190(63.3 \%) \\
300(100 \%)\end{array}$ & $\begin{array}{c}\chi_{\text {cal }}^{2}=0.012, \mathrm{df}=1 \\
\chi_{\text {tab }}^{2}=2.71 \\
\rho=0.913\end{array}$ & Insignificant \\
\hline $\begin{array}{c}\text { Increasing Diabetes because of } \\
\text { Food Habit } \\
\text { No } \\
\text { Yes } \\
\text { Total } \\
\end{array}$ & $\begin{array}{l}37(12.3 \%) \\
41(13.7 \%) \\
78(26.0 \%) \\
\end{array}$ & $\begin{array}{l}110(36.7 \%) \\
112(37.3 \%) \\
222(74.0 \%) \\
\end{array}$ & $\begin{array}{l}147(49.0 \%) \\
153(51.0 \%) \\
300(100 \%) \\
\end{array}$ & $\begin{array}{c}\chi_{\text {cal }}^{2}=0.103, \mathrm{df}=1 \\
\chi_{\text {tab }}^{2}=2.71 \\
\rho=0.748\end{array}$ & Insignificant \\
\hline $\begin{array}{c}\text { Controlling Diabetic through Diet- } \\
\text { ing } \\
\text { No } \\
\text { Yes } \\
\text { Total } \\
\end{array}$ & $\begin{array}{c}2(0.7 \%) \\
75(25.1 \%) \\
77(25.8 \%) \\
\end{array}$ & $\begin{array}{c}5(1.7 \%) \\
217(72.6 \%) \\
222(74.2 \%) \\
\end{array}$ & $\begin{array}{c}7(2.3 \%) \\
292(97.7 \%) \\
299(100 \%) \\
\end{array}$ & $\begin{array}{c}\chi_{\text {cal }}^{2}=0.030, \mathrm{df}=1 \\
\chi_{\text {tab }}^{2}=2.71 \\
\rho=0.863\end{array}$ & Insignificant \\
\hline $\begin{array}{c}\text { Controlling Diabetic through Exer- } \\
\text { cise } \\
\text { No } \\
\text { Yes } \\
\text { Total } \\
\end{array}$ & $\begin{array}{l}23(7.7 \%) \\
55(18.3 \%) \\
78(26.0 \%)\end{array}$ & $\begin{array}{l}44(14.7 \%) \\
178(59.3 \%) \\
222(74.0 \%) \\
\end{array}$ & $\begin{array}{l}67(22.3 \%) \\
233(77.7 \%) \\
300(100 \%) \\
\end{array}$ & $\begin{array}{c}\chi_{c a l}^{2}=3.110, \mathrm{df}=1 \\
\chi_{\text {tab }}^{2}=2.71 \\
\rho=0.078\end{array}$ & Significant \\
\hline $\begin{array}{l}\text { Controlling Diabetic through taking } \\
\text { Medicine } \\
\text { No } \\
\text { Yes } \\
\text { Total }\end{array}$ & $\begin{array}{l}67(22.3 \%) \\
11(3.7 \%) \\
78(26.0 \%)\end{array}$ & $\begin{array}{l}94(31.3 \%) \\
128(42.7 \%) \\
222(74.0 \%)\end{array}$ & $\begin{array}{l}161(53.7 \%) \\
139(46.3 \%) \\
300(100 \%)\end{array}$ & $\begin{array}{c}\chi_{\text {cal }}^{2}=44.036, \mathrm{df}=1 \\
\chi_{\text {tab }}^{2}=2.71 \\
\rho=0.000\end{array}$ & Significant \\
\hline $\begin{array}{c}\text { Time Spending in Walking } \\
<=30 \text { Minutes } \\
\text { 31-60 Minutes } \\
60+\text { Minutes } \\
\text { Total } \\
\end{array}$ & $\begin{aligned} & 38(12.7 \%) \\
& 35(11.7 \%) \\
& 5(1.7 \%) \\
& 78(26.0 \%) \\
&\end{aligned}$ & $\begin{array}{c}116(38.7 \%) \\
88(29.3 \%) \\
18(6.0 \%) \\
222(74.0 \%) \\
\end{array}$ & $\begin{array}{l}154(51.3 \%) \\
123(41.0 \%) \\
23(7.7 \%) \\
300(100 \%) \\
\end{array}$ & $\begin{array}{c}\chi_{c a l}^{2}=0.743, \mathrm{df}=2 \\
\chi_{\text {tab }}^{2}=4.61 \\
\rho=0.690\end{array}$ & Insignificant \\
\hline $\begin{array}{c}\text { Calorie Intake according to DFT } \\
1000-1500 \text { Calorie } \\
1600-1800 \text { Calorie } \\
1800+\text { Calorie } \\
\text { Total }\end{array}$ & $\begin{array}{c}62(20.8 \%) \\
15(5.0 \%) \\
1(0.3 \%) \\
78(26.2 \%)\end{array}$ & $\begin{array}{c}177(59.4 \%) \\
34(11.4 \%) \\
9(3.0 \%) \\
220(73.8 \%)\end{array}$ & $\begin{array}{c}239(80.2 \%) \\
49(16.4 \%) \\
10(3.4 \%) \\
298(100 \%)\end{array}$ & $\begin{array}{c}\chi_{\text {cal }}^{2}=1.860, \mathrm{df}=2 \\
\chi_{\text {tab }}^{2}=4.61 \\
\rho=.395\end{array}$ & Insignificant \\
\hline $\begin{array}{c}\text { Living House of Respondents } \\
\text { Building } \\
\text { Tin Shed } \\
\text { Mud Made } \\
\text { Total }\end{array}$ & $\begin{array}{l}34(11.3 \%) \\
25(8.3 \%) \\
19(6.3 \%) \\
78(26.0 \%)\end{array}$ & $\begin{array}{l}65(21.7 \%) \\
107(35.7 \%) \\
50(16.7 \%) \\
222(74.0 \%)\end{array}$ & $\begin{array}{l}99(33.0 \%) \\
132(44.0 \%) \\
69(23.0 \%) \\
300(100 \%)\end{array}$ & $\begin{array}{c}\chi_{c a l}^{2}=7.087, \mathrm{df}=2 \\
\chi_{\text {tab }}^{2}=4.61 \\
\rho=0.029\end{array}$ & Significant \\
\hline
\end{tabular}


Table 2. Logistic Regression for the Effects of Selected Independent Variables on Type 2 Diabetes as a Dependent Variable

\begin{tabular}{|c|c|c|c|c|c|c|}
\hline \multirow[b]{2}{*}{ Variables } & \multirow[b]{2}{*}{ Coefficient $(\beta)$} & \multirow{2}{*}{$\begin{array}{l}\text { S.E of Esti- } \\
\text { mates }(\beta)\end{array}$} & \multirow[b]{2}{*}{ Significance $(\rho)$} & \multirow{2}{*}{$\begin{array}{l}\text { Relative Risk or } \\
\text { Odds Ratio } \\
\{\operatorname{Exp}(\beta)\}\end{array}$} & \multicolumn{2}{|c|}{$95.0 \%$ C.I. for $\operatorname{EXP}(\beta)$} \\
\hline & & & & & Lower & Upper \\
\hline $\begin{array}{c}\text { Age } \\
\text { Early Age }(<35 \text { years })[\mathrm{ref} .] \\
\text { Middle Age }(35-50 \text { years }) \\
\text { Older Age }(>50 \text { years }) \\
\end{array}$ & $\begin{array}{l}1.266 \\
0.636\end{array}$ & $\begin{array}{l}\ldots \ldots \ldots \ldots \\
0.544 \\
0.569\end{array}$ & $\begin{array}{l}0.020 \\
0.264\end{array}$ & $\begin{array}{l}1.000 \\
3.545 \\
1.890\end{array}$ & $\begin{array}{l}1.221 \\
0.619 \\
\end{array}$ & $\begin{array}{c}10.292 \\
5.766 \\
\end{array}$ \\
\hline $\begin{array}{c}\text { Sex } \\
\text { Male [ref.] } \\
\text { Female }\end{array}$ & 0.383 & 0.433 & 0.376 & $\begin{array}{l}1.000 \\
1.467\end{array}$ & 0.628 & 3.426 \\
\hline $\begin{array}{c}\text { Education } \\
\text { Illiterate [ref.] } \\
\text { Literate }\end{array}$ & -0.364 & 0.377 & $\begin{array}{c}\ldots . \ldots \ldots \\
0.334 \\
\end{array}$ & $\begin{array}{l}1.000 \\
0.695 \\
\end{array}$ & 0.332 & 1.455 \\
\hline $\begin{array}{c}\text { Occupation } \\
\text { Non Professional [ref.] } \\
\text { Professional }\end{array}$ & $\begin{array}{c}\ldots \ldots \ldots \\
0.876\end{array}$ & 0.415 & ${ }_{0.035}$ & $\begin{array}{l}1.000 \\
2.400\end{array}$ & 1.064 & 5.417 \\
\hline $\begin{array}{c}\text { Duration of Suffering from Diabetic } \\
<1 \text { year [ref.] } \\
1-5 \text { years } \\
6-10 \text { years } \\
>10 \text { years }\end{array}$ & $\begin{array}{l}\cdots \ldots \ldots \\
-0.197 \\
-0.419 \\
0.560\end{array}$ & $\begin{array}{l}0.428 \\
0.475 \\
0.607\end{array}$ & $\begin{array}{l}0.645 \\
0.378 \\
0.356\end{array}$ & $\begin{array}{l}1.000 \\
0.821 \\
0.658 \\
1.751\end{array}$ & $\begin{array}{l}0.355 \\
0.259 \\
0.532\end{array}$ & $\begin{array}{l}1.899 \\
1.669 \\
5.757\end{array}$ \\
\hline $\begin{array}{c}\text { Duration of Sleeping } \\
\text { Less than Normal }(<6 \text { hours }) \text { [ref.] } \\
\text { Normal }(6 \text { hours }) \\
\text { More than Normal }(>6 \text { hours })\end{array}$ & $\begin{array}{l}-0.195 \\
0.491 \\
\end{array}$ & $\begin{array}{l}0.466 \\
0.409\end{array}$ & $\begin{array}{l}0.676 \\
0.231\end{array}$ & $\begin{array}{l}1.000 \\
0.823 \\
1.633\end{array}$ & $\begin{array}{l}0.330 \\
0.732\end{array}$ & $\begin{array}{l}2.050 \\
3.644 \\
\end{array}$ \\
\hline $\begin{array}{c}\text { Existence of any Diabetic Patients in the } \\
\text { Family } \\
\text { No [ref.] } \\
\text { Yes }\end{array}$ & -0.108 & 0.345 & 0.754 & $\begin{array}{l}1.000 \\
0.898\end{array}$ & 0.457 & 1.765 \\
\hline $\begin{array}{c}\text { Control Diabetic (By Dieting) } \\
\text { No [ref.] } \\
\text { Yes }\end{array}$ & $\begin{array}{l}\ldots \ldots \ldots \ldots \\
1.771\end{array}$ & $\begin{array}{c}\ldots \ldots \ldots \\
0.710\end{array}$ & $\begin{array}{c}0.013 \\
0 . \ldots \ldots \ldots\end{array}$ & $\begin{array}{l}1.000 \\
5.876\end{array}$ & 1.460 & 23.648 \\
\hline $\begin{array}{c}\text { Control Diabetic(By Exercise) } \\
\text { No [ref.] } \\
\text { Yes } \\
\end{array}$ & 1.608 & 0.453 & 0.000 & $\begin{array}{l}1.000 \\
4.991 \\
\end{array}$ & 2.054 & 12.129 \\
\hline $\begin{array}{c}\text { Control Diabetic (Taking Medicine) } \\
\text { No [ref.] } \\
\text { Yes }\end{array}$ & $\begin{array}{c}\ldots \ldots \ldots \\
2.517\end{array}$ & $\begin{array}{c}\ldots \ldots \ldots \\
0.407\end{array}$ & $\begin{array}{l}\ldots \ldots \ldots \ldots \\
0.000\end{array}$ & $\begin{array}{c}1.000 \\
12.390\end{array}$ & 5.575 & 27.534 \\
\hline $\begin{array}{c}\text { Over Weight } \\
\text { No [ref.] } \\
\text { Yes } \\
\end{array}$ & 0.067 & 0.761 & 0.930 & $\begin{array}{l}1.000 \\
1.069 \\
\end{array}$ & 0.241 & 4.747 \\
\hline $\begin{array}{c}\text { Normal Weight } \\
\text { No [ref.] } \\
\text { Yes }\end{array}$ & $\begin{array}{l}\ldots \ldots \ldots \ldots \\
-0.400\end{array}$ & $\begin{array}{c}\ldots \ldots \ldots \ldots \\
0.719\end{array}$ & 0.578 & $\begin{array}{l}1.000 \\
0.670\end{array}$ & 0.164 & 2.745 \\
\hline $\begin{array}{c}\text { Increasing Diabetes because of Food } \\
\text { Habit } \\
\text { No [ref.] } \\
\text { Yes } \\
\end{array}$ & -0.536 & $\begin{array}{c}\ldots \ldots \ldots \\
0.344\end{array}$ & $\begin{array}{c}0.119 \\
0.1 \% \ldots \\
\end{array}$ & $\begin{array}{l}1.000 \\
0.585 \\
\end{array}$ & 0.298 & 1.148 \\
\hline $\begin{array}{c}\text { Blood Pressure } \\
\text { Normal [ref.] } \\
\text { More than Normal } \\
\text { Less than Normal }\end{array}$ & $\begin{array}{l}-0.081 \\
-0.207\end{array}$ & $\begin{array}{l}\ldots \ldots \ldots \ldots \\
0.373 \\
0.574\end{array}$ & $\begin{array}{l}0.828 \\
0.718\end{array}$ & $\begin{array}{l}1.000 \\
0.922 \\
0.813\end{array}$ & $\begin{array}{l}0.444 \\
0.264\end{array}$ & $\begin{array}{l}1.917 \\
2.505\end{array}$ \\
\hline $\begin{array}{l}\text { Time Spending in Walking } \\
<=30 \text { Minutes [ref.] } \\
\text { 31-60 Minutes } \\
60+\text { Minutes }\end{array}$ & $\begin{array}{l}-1.057 \\
-1.017\end{array}$ & $\begin{array}{l}\ldots \ldots \ldots \ldots \\
0.409 \\
0.654\end{array}$ & $\begin{array}{l}0.010 \\
0.120\end{array}$ & $\begin{array}{l}1.000 \\
0.347 \\
0.362\end{array}$ & $\begin{array}{l}0.156 \\
0.100\end{array}$ & $\begin{array}{l}0.775 \\
1.302\end{array}$ \\
\hline $\begin{array}{c}\text { Calorie intake according to Diabetic Food } \\
\text { Table } \\
1000-1500 \text { Calorie }[\text { ref.] } \\
1600-1800 \text { Calorie } \\
1800+\text { Calorie }\end{array}$ & $\begin{array}{l}-0.779 \\
0.281\end{array}$ & $\begin{array}{l}0.481 \\
0.886\end{array}$ & $\begin{array}{l}\ldots \ldots \ldots \\
0.105 \\
0.751\end{array}$ & $\begin{array}{l}1.000 \\
0.459 \\
1.325\end{array}$ & $\begin{array}{l}0.179 \\
0.234\end{array}$ & $\begin{array}{l}1.178 \\
7.516\end{array}$ \\
\hline $\begin{array}{c}\text { Living House of the Respondents } \\
\text { Building [ref.] } \\
\text { Tin Shed } \\
\text { Mud Made }\end{array}$ & $\begin{array}{l}0.948 \\
0.351\end{array}$ & $\begin{array}{l}0.394 \\
0.485\end{array}$ & $\begin{array}{l}0.016 \\
0.469\end{array}$ & $\begin{array}{l}1.000 \\
2.581 \\
1.421\end{array}$ & $\begin{array}{l}1.191 \\
0.549\end{array}$ & $\begin{array}{l}5.591 \\
3.676\end{array}$ \\
\hline & $=0.330991, \mathrm{C}$ & $\begin{array}{l}\text { Snell R Sq } \\
\text { age }=0.0766\end{array}$ & $\begin{array}{l}0.407 \\
\text { tability of } \mathrm{R}^{2}=\end{array}$ & & & \\
\hline
\end{tabular}


Again the regression coefficients of the respondents whose time spending in walking are 31-60 minutes and 60+ minutes are -1.057 and -1.017 respectively and the corresponding odds ratio are 0.347 and 0.362 which indicates that the risk of type 2 diabetes of the respondents whose time spending in walking are 31-60 minutes and 60+ minutes are 0.347 times and 0.362 times lower than that of the respondents whose time spending in walking are $<=30$ minutes.

The regression coefficients of the respondents who daily intake 1600-1800 calorie and $1800+$ calorie according to DFT are -0.779 and 0.281 and the corresponding odds ratio are 0.459 and 1.325 respectively. It indicates that the risk of type 2 diabetes of the respondents who daily intake 1600-1800 calorie and $1800+$ calorie according to DFT are 0.459 times lower and 1.325 times higher than that of the respondents who daily intake 1000-1500 calorie according to DFT. So, it is clear that the respondents who daily intake more calorie have high risk to develop type 2 diabetes.

The regression coefficients of the respondents whose living house is tin shed and mud made are 0.948 and 0.351 respectively and the corresponding odds ratio are 2.581 and 1.421 which indicates that the risk of type 2 diabetes of the respondents whose living house is tin shed and mud made are 2.581 times and 1.421 times higher than that of the respondents whose living house is building.

\section{Conclusions and Recommendations}

In this study, it is observed that people are more affected in middle (35-50 years) and older ( $>50$ years) ages by type 2 diabetes which is $66.3 \%$. Of those, female (43.7\%) are more affected than male (35.7\%). The majority number of diabetes patients (36.3\%) is suffering from diabetes less than one year in which $26.7 \%$ patients have type 2 diabetes. $35 \%$ type 2 diabetic patients are sleeping more than normal $(>6)$ hours and $47 \%$ type 2 diabetic patients have one or more diabetic patients in their family. Most of the type 2 diabetic patients $(38.7 \%)$ are spending their time in walking for $\leq 30$ minutes. Again, $35.7 \%$ type 2 diabetic patients' living house is tin shed which implies that type 2 diabetes affects more in low income group. It is found that age, controlling diabetic through exercise, controlling diabetic through taking medicine and living house of the respondents are significantly associated with the type 2 diabetes of diabetic patients. Again, it has been identified that respondent's age, occupation, controlling diabetic through dieting, controlling diabetic through exercise, controlling diabetic through taking medicine, time spending in walking and living house of the respondents have statistically significant effect on type 2 diabetes and increasing diabetes because of food habit and calorie intake according to diabetic food table have statistically approximately significant effect on type 2 diabetes.

Since type 2 diabetes is mostly common of the diabetic patients in Bangladesh, it may be one of the major impediments of healthy life as well as economic growth. In this study, some recommendations for controlling diabetes as well as for better health are given:

(i) To exercise regularly with increasing physical activities and to control blood pressure especially high blood pressure. If persons have over weight and obesity, they must have to lose the extra weight of the body and everyone should sleep normal hours (6 hours).

(ii) To avoid the habit of unnecessary eating and take foods with high fiber.

(iii) To provide the adequate availability and access of health services and to provide correct information about diabetes to the people through various media.

\section{REFERENCES}

[1] S. A. Meo, Significance of spirometry in diabetic patients. International Journal of Diabetes Mellitus 2(1), 47-50, 2010.

[2] S. Wild, G. Roglic, A. Green, R. Sicree and H.King, Global prevalence of diabetes: estimates for the year 2000 and projections for 2030. Diabetes Care 27, 1047-1053, 2004.

[3] American Diabetes Association, National Diabetes Statistics, 2007.

[4] M. A. Rahim, S. Vaaler, S. M. K. Ali, A. K. A Khan, A. Hussain and Q. Nahar, Prevalence of type 2 diabetes in urban slums of Dhaka, Bangladesh. Bangladesh Medical Research Council Bulletin 20, 60-70, 2004.

[5] M. A. Sayeed, H. Mahtab, P. A. Khanam, K. A. Ahsan, A. Banu and A. N. Rashid, Diabetes and impaired fasting glycemia in the tribes of Khagrachari hill tracts of Bangladesh. Diabetes Care 27, 1054-1059, 2004.

[6] M. A. Rahim, A. Hussain, A. K. A. Khan, M. A. Sayeed, and S. M. K. Ali, Rising prevalence of type 2 diabetes in rural Bangladesh: a population based study. Diabetes Research and Clinical Practice 77, 300-305, 2007.

[7] BIRDEM Hospital Overview, 2010.

[8] K. Kasim, M. Amar, A. A. E. Sadek, and S. A. Gawad, Peripheral neuropathy in type 2 diabetic patients attending diabetic clinics in Al-Azhar University Hospitals, Egypt. International Journal of Diabetes Mellitus 2(1), 20-23, 2010.

[9] S. Sanchez-Viveros, S. Barquera, C. E. Medina-Solis, M. C. Velazquez-Alva and R. Valdez, Association between diabetes mellitus and hypertension with anthropometric indicators in older adults: results of the Mexican health survey, 2000. The Journal of Nutrition, Health \& Aging 12(5), 327-333, 2008.

[10] S. M. Kim, J. S. Lee, J. Lee, J. K. Na, J. H. Han, D. K. Yoon, S. H. Baik, D. S. Choi and K. M. Chi, Prevalence of diabetes and impaired fasting in Korea. Diabetes Care 29, 226-232, 2006.

[11] A. Bener, M. Zirie and A.Al-Rakabi, Genetics, obesity and environmental risk factors associated with type 2 diabetes. Croatian Medical Journal 46, 302-307, 2005.

[12] A. Gupta, R. Gupta, M. Sarna, S. Rastogi, V. P. Gupta and K.Kothari, Prevalence of diabetes, impaired fasting glucose and insulin resistance syndrome in an Indian population. Diabetes Research and Clinical Practice 61, 69-76, 2003. 
[13] A. M. Habori, A. M. Mamari and A. A. Meeri, Type 2 diabetes mellitus and impaired glucose tolerance in Yemen: prevalence associated metabolic changes and risk factors. Diabetes Research and Clinical Practice 65, 275-281, 2004.

[14] A. Hussain, S. Vaaler, M. A. Sayeed, H. Mahtab, S. M. K. Ali and A. K. A Khan,. Type 2 diabetes and impaired fasting blood glucose in rural Bangladesh: a population-based study. The European Journal of Public Health 17(3), 291-296, 2007.

[15] BBS, Bangladesh Population Census-2001, Planning Division, Ministry of Planning, Govt. of Bangladesh, 2003.

[16] V. V. Gossain and S.Aldasouqi, The challenge of undiagnosed pre-diabetes, diabetes and associated cardiovascular disease. International Journal of Diabetes Mellitus 2(1), 43-46, 2010.

[17] ICDDR,B, Type 2 diabetes and pre-diabetic conditions among adults aged 27-50 years in Matlab: a hidden public health burden. Health and Science Bulletin 7(2), 13-18, 2009.

[18] G. Li, P. Zhang, J. Wang, E. W. Gregg, W. Yang and Q. Gong, The long-term effect of lifestyle interventions to prevent diabetes in the China Da Qing Diabetes Prevention Study: a 20-year follow-up study. Lancet 371, 1783-1789, 2008.

[19] J. Tuomilehto, Primary prevention of type 2 diabetes: lifestyle intervention works and saves money, but what should be done with smokers? Annals of Internal Medicine 142, 381-383,
2005.

[20] W. C. Knowler, E. Barrett-Connor, S. E. Fowler, R. F. Hamman, J. M. Lachin and E. A. Walker, Reduction in the incidence of type 2 diabetes with lifestyle intervention or metformin. The New England Journal of Medicine 346, 393-403, 2002

[21] D.R. Cox, The analysis of binary data. London, Methuen, Chapman and Hall, 1970.

[22] E.T. Lee, Statistical methods for survival data analysis. Life-time Learning Publications, Belmont, CA, 1980.

[23] Fox, J.D. Linear statistical models and related methods. Wiley and Sons, New York, 1984.

[24] J. Stevens, Applied Multivariate Statistics for the Social Sciences, Third Edition, Lawrence Erlbaum Associates, Inc., Publishers, New Jersey, 1996

[25] A. Ramachandran, C.Snehalatha, and V. Vijay, Temporal changes in prevalence of type 2 diabetes and impaired glucose tolerance in urban southern India. Diabetes Research and Clinical Practice 58, 55-60, 2002

[26] C. Snehalatha, A. Ramachandran, A. Kapur and V. Vijay, Age-specific prevalence and risk associations for impaired glucose tolerance in urban southern Indian population. Journal of Association of Physicians of India 51, 766-769, 2003 